\title{
Measurement of Truck Cab Flow in Support of Wind Turbine Testing
}

Scott M. Larwood

National Wind Technology Center

Golden, $\mathrm{CO}$

Brian Acker, Jim Sencenbaugh

WindLite Corporation

Mountain View, CA

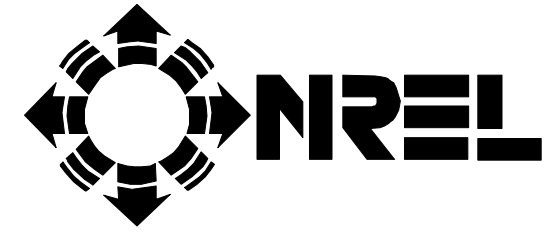

National Renewable Energy Laboratory 1617 Cole Boulevard

Golden, Colorado 80401-3393

A national laboratory of the U.S. Department of Energy Managed by Midwest Research Institute for the U.S. Department of Energy under Contract No. DE-AC36-83CH10093 


\section{Measurement of Truck Cab Flow in Support of Wind Turbine Testing}

Scott M. Larwood

National Wind Technology Center

Golden , $\mathrm{CO}$

Brian Acker, Jim Sencenbaugh

WindLite Corporation

Mountain View, $C A$

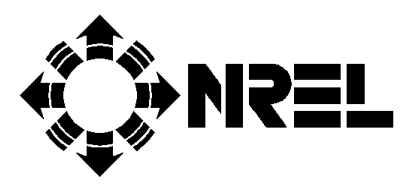

National Renewable Energy Laboratory 1617 Cole Boulevard

Golden, Colorado 80401-3393

A national laboratory of the U.S. Department of Energy Managed by Midwest Research Institute for the U.S. Department of Energy under contract No. DE-AC36-83CH10093

Work performed under Task No. WE902330

November 1998 


\section{NOTICE}

This report was prepared as an account of work sponsored by an agency of the United States government. Neither the United States government nor any agency thereof, nor any of their employees, makes any warranty, express or implied, or assumes any legal liability or responsibility for the accuracy, completeness, or usefulness of any information, apparatus, product, or process disclosed, or represents that its use would not infringe privately owned rights. Reference herein to any specific commercial product, process, or service by trade name, trademark, manufacturer, or otherwise does not necessarily constitute or imply its endorsement, recommendation, or favoring by the United States government or any agency thereof. The views and opinions of authors expressed herein do not necessarily state or reflect those of the United States government or any agency thereof.

Available to DOE and DOE contractors from:

Office of Scientific and Technical Information (OSTI)

P.O. Box 62

Oak Ridge, TN 37831

Prices available by calling 423-576-8401

Available to the public from:

National Technical Information Service (NTIS)

U.S. Department of Commerce

5285 Port Royal Road

Springfield, VA 22161

703-605-6000 or 800-553-6847

or

DOE Information Bridge

http://www.doe.gov/bridge/home.html

Printed on paper containing at least $50 \%$ wastepaper, including $20 \%$ postconsumer waste 


\section{Preface}

This report describes an experiment to measure the airflow over a truck cab that can be used to conduct steady-state tests on an $8-\mathrm{kW}$ wind turbine. The cab airflow measurements were made to document the turbine inflow for analytical models. The airflow measurements were made with an array of anemometers positioned to represent the turbine rotor disk. The data showed that the influence of the truck cab was primarily in the lower sector of the rotor disk. The influence was negligible in the rest of the rotor disk. 


\section{Executive Summary}

\section{Introduction}

WindLite Corporation of Mountain View, California, developed an 8-kW wind turbine under the U.S. Department of Energy's Small Wind Turbine Project. WindLite proposed testing the turbine on a truck flatbed while driving the truck down a runway at constant relative wind speed. The primary objective of the truck test was to optimize the turbine's furling behavior. The data could also be used to advance furling analytical models.

A concern at the beginning of the test program was what influence the truck cab would have on the rotor inflow and thus the turbine behavior. Therefore an experiment was proposed to measure the rotor inflow without the turbine installed.

\section{Approach}

We constructed an array of anemometers to measure the airflow at locations around an area representative of the rotor disk. The array could also be yawed to measure the inflow at yawed rotor positions. A reference anemometer and wind direction sensor were positioned forward of the truck cab at turbine hub height.

We first calibrated the array anemometers against the reference anemometer on a rig placed forward of the cab. The array was then erected with the anemometers and the truck was driven down the runway at speeds and yaw angles representative of turbine operation. The array anemometer data were then normalized to the reference anemometer wind speed.

\section{Results}

The data showed that at wind directions below $5^{\circ}$ off the truck line of travel, the influence of the cab on the rotor inflow was negligible with exception to the lower-most sector of the rotor disk. This area was characterized by increased turbulence and wind speed deficit that increased with wind speed. 


\section{Contents}

Page
Introduction
Background
Test Objectives
Anemometer Array
Datibration Rig Acquisition

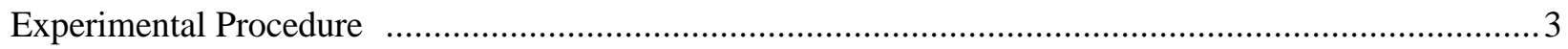

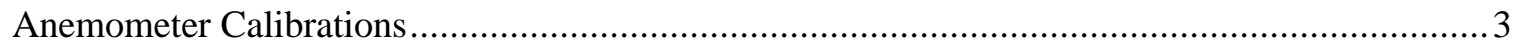

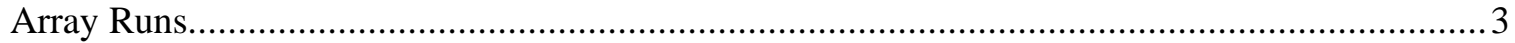

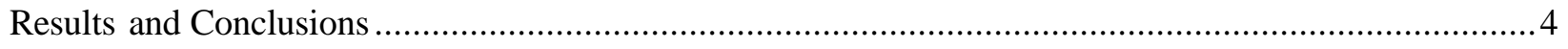

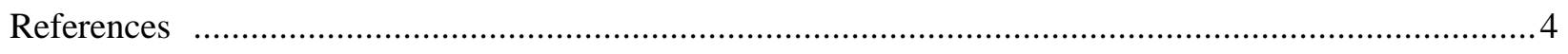

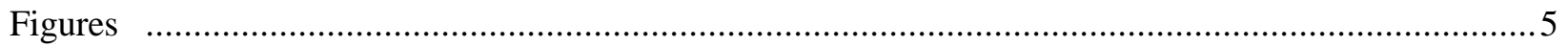


TP-500-25714

\section{Introduction}

\section{Background}

The U.S. Department of Energy (DOE) sponsors a multi-project Turbine Development Program to assist the U.S. wind industry in developing competitive, high performance technology for global energy markets. From its inception in 1990 until 1995, the program focused on developing utility-grade wind turbine systems for use in large wind power plants. DOE added the Small Wind Turbine Project to the program in 1995 to stimulate the application of advanced technology in the portion of industry that serves specialized markets requiring wind turbines in sizes from 5 to $40 \mathrm{~kW}$.

The goal of the Small Wind Turbine Project is to help U.S. industry develop cost-effective, high reliability, small wind turbine systems for both the domestic and international wind energy markets. In 1997, the National Renewable Energy Laboratory awarded four manufacturers won project contracts to develop, manufacture, and test new wind turbines. WindLite of Mountain View, California, proposed the development of an 8-kW machine based on the Sencenbaugh Wind Electric SWE-1000 turbine built in the late 1970s and 1980s.

The WindLite Turbine is a three-bladed turbine with a tail fin for yaw control. The turbine uses horizontal furling to regulate rotor speed and power. Furling occurs as the rotor thrust increases in high winds causing the rotor to pivot about a hinge relative to the tail. A critical design issue is the wind speed at which the furling occurs.

We determined at the beginning of the program that current analytical models of turbine furling behavior were inadequate to be used as design tools. This was due to lack of experimental data to correlate with analytical models. Therefore, an experiment was proposed to optimize the turbine geometry for furling. The experiment consists of placing the turbine on the back of a flatbed truck and driving the truck down an aircraft runway at various speeds. The turbine would have variable geometry so that the onset of furling could be optimized. Similar truck tests were conducted previously on the SWE-1000 turbine in 1976. The new tests were to be conducted at the NASA Ames Moffett Airfield in California.

The truck tests would assist in determining the optimum geometry for furling, along with improving furling analytical models. However, the main uncertainty in the truck test was how the rotor inflow over the truck cab would differ from free air conditions. We could not find any information on this topic from a literature review. The majority of truck cab aerodynamic research has focused on drag measurements of tractor/trailer combinations; an example is reference 1 . The flow over the cab in this configuration is highly influenced by the trailer. Therefore, an experiment was proposed to measure the rotor inflow over the cab prior to the turbine tests. This inflow test, called the Anemometer Array Test, is the subject of this report. This test was conducted prior to the turbine truck test.

\section{Objectives}

The objectives of the Anemometer Array Test were to document the flow behind the truck cab in support of turbine truck tests. The flow would be measured at various truck speeds and at various array yaw angles. The Anemometer Array Test data would be used to correlate truck test data with turbine analytical models by adjusting the inflow models. 
TP-500-25714

\section{Experimental Setup}

\section{Anemometer Array}

We designed and built a structure to measure the wind speed with anemometers over an area representative of the turbine rotor disk. Figure 1 shows the anemometer array by itself and placed on the truck with reference dimensions. All anemometers were NRG Model 40C. In addition to the array, a reference anemometer along with a wind direction sensor (NRG Model 200P) was placed on the boom, forward of the cab. Also shown in the figure is the numbering scheme for the anemometers. Note that anemometer 8 was positioned directly behind the cab.

The array measured the wind speed on the rotor disc at 50\% and 100\% radial stations and at 4-azimuthal positions. The array could also be rotated in yaw from $0^{\circ}$ to $90^{\circ}$ in $5^{\circ}$ fixed increments to measure the inflow for the yawed turbine rotor. The array was rotated in a counterclockwise direction viewed from the top. Note that the center of the array was positioned 32.5 inches horizontally from the center of rotation in order to duplicate the turbine rotor position.

The array was constructed of square steel beams fastened to the hub center and supported at the ends and midpoints by guy wires. The anemometers were positioned 8.5 inches upstream of the beams. The center of the array was fastened to the tower that would be used for the turbine testing. The tower with the array installed was erected using a gin pole/winch arrangement. During the array runs some azimuth rocking of the array was observed at the higher truck speeds.

\section{Calibration Rig}

The array anemometers were calibrated on site against a factory-calibrated anemometer. The Anemometer Calibration rig is shown in Figure 2. The rig was designed to hold the eight anemometers used on the array along with the calibrated reference anemometer placed in the center. One of the outermost anemometers was also a factory-calibrated unit. Comparison between the two calibrated anemometers documented the lateral wind speed difference along the rig. All anemometers were placed 18.75 inches (2.5 diameters) apart. The calibration array was installed on a boom that was installed on the front bumper. This was the same boom that held the reference anemometer and wind direction sensor. Guy wires connected to the truck cab roof supported the tips of the rig and reduced rig vibration.

\section{Data Acquisition System}

Figure 3 shows a schematic of the data acquisition system. The data were acquired with a Campbell Scientific $21 \mathrm{X}$ data logger. The sampling frequency was set at $5 \mathrm{~Hz}$ with a 1 -second averaging period. A laptop computer was connected to the $21 \mathrm{X}$ for data storage and analysis.

The anemometers produced a 6-volt AC (typical) sine wave in which the frequency changed linearly with wind speed. Two of the anemometers were calibrated by NRG to be used as reference units. The anemometers were wired to a custom-built frequency-to-voltage converter. The frequency to voltage converter was designed to output $200 \mathrm{mV}$ for $1 \mathrm{~Hz}$ anemometer input. The voltage outputs were then connected to the $21 \mathrm{X}$ datalogger. The frequency-to-voltage conversion was used instead of the $21 \mathrm{X}$ counter input to increase the signal resolution over the sampling period. Another output from the converter provided a scaled voltage output of anemometer 1 that was connected to a digital readout. The truck driver used this readout to maintain a constant wind velocity while driving down the runway. 
The wind direction sensor was positioned with the dead band aligned $90^{\circ}$ to the truck long axis. This angle was subtracted from the raw data so that a reading of $0^{\circ}$ corresponded to a wind direction parallel to the path of the truck. Positive wind direction corresponded to wind coming from the right hand side of the truck.

\section{Experimental Procedure}

\section{Anemometer Calibrations}

The array anemometers were installed on the calibration rig forward of the truck cab. One factorycalibrated anemometer was placed in the center of the rig (reference anemometer) and another was placed at the left-most (view from truck cab) position of the rig. These anemometers were connected to calibrated channels on the frequency-to-voltage converter to record wind speed directly to the datalogger.

The truck was driven down the runway and the wind speed was maintained at 6.7, 9.0, 11.0 and $13.4 \mathrm{~m} / \mathrm{s}$ for roughly 2 minutes at each speed. The anemometer data were then plotted against the reference anemometer wind speed. The sensitivity and offset for each anemometer was determined with a linear regression fit. These values were programmed in the $21 \mathrm{X}$ for the array runs.

The outermost calibrated anemometer was plotted against the reference anemometer to document the lateral variation in wind speed along the calibration rig. Using a linear regression fit of the data, a reference anemometer speed of $13.4 \mathrm{~m} / \mathrm{s}$ resulted in a $0.09 \%$ difference in the outermost calibrated anemometer. It was concluded from this information that the lateral variation was negligible.

\section{Array Runs}

The calibration rig was removed from the front of the rig and the reference anemometer and wind vane were installed in its place. The Anemometer Array was constructed onto the turbine tower top and the tower was erected.

The truck was driven down the runway at the same wind speeds as the calibration runs for 2 minutes at each speed. After completing the wind speed sweep the array was rotated $5^{\circ}$ and the run was repeated. Due to schedule constraints, we only tested up to an $80^{\circ}$ array angle. Not all wind speeds were tested either, due to ambient wind speeds on the runway higher than the test wind speeds, and wind directions greater than $20^{\circ}$ off the truck line of travel. 


\section{Results and Conclusions}

The data were separated by array angle and again by wind speed. The array anemometers (2-9) were normalized by the reference anemometer (1). The anemometer data at each position were then averaged over the wind speed range for each array angle tested. Figure 4 shows the normalized data using circular segments to represent the anemometer position. The measurement represents a point representation and should not be interpreted as an average measurement over the area. Also, for each array angle run the average wind direction is presented. Note that with increasing truck speed the wind direction would move towards $0^{\circ}$. Figure 5 shows the data presented such that the normalized anemometer speed is plotted against array angle. This data is reduced so that only average wind directions of less than $5^{\circ}$ are presented.

The signal time-series were then plotted for the array runs. Figure 6 shows anemometer 4 plotted with anemometer 1 (offset by $2 \mathrm{~m} / \mathrm{s}$ ) for a $10^{\circ}$ array angle. The traces follow each other closely with some higher frequency components on the array anemometer. This figure is typical of all anemometer data for all array runs with the exception of anemometer 8 . Figure 7 shows anemometer 8 plotted with anemometer 1 (no offset) for the $10^{\circ}$ array angle. Note the higher frequency of the array signal and the velocity difference growing with wind speed. Figure 8 shows anemometer 8 and 1 time-series at $60^{\circ}$ array angle; with the velocity difference minimized but the high frequency component remaining. The higher frequency component of the array time-series is an indication of turbulence generated by the flow over the truck cab.

We conclude from the data that the lateral and horizontal wind speed variation over the rotor disk is negligible with exception to the lower sector immediately behind the truck cab. We expected that the wind speed decrement in this location would increase the pitching moment and blade cyclic loads for the turbine tests. The lateral variation in this sector was not measured; therefore the impact on the turbine furling behavior was uncertain. More measurements in the lower quadrant between anemometers 4 and 8 would be recommended if further array tests were conducted.

\section{References}

1. Mason, W. T. Jr.; Beebe, P. S., "Drag Related Flow Field Characteristics of Trucks and Buses," Symposium on Aerodynamic Drag Mechanisms of Bluff Bodies and Road Vehicles, September 27-28, 1976; General Motors Research Laboratory, Warren, Michigan. New York: Plenum Press; 1978. 


\section{Figures}

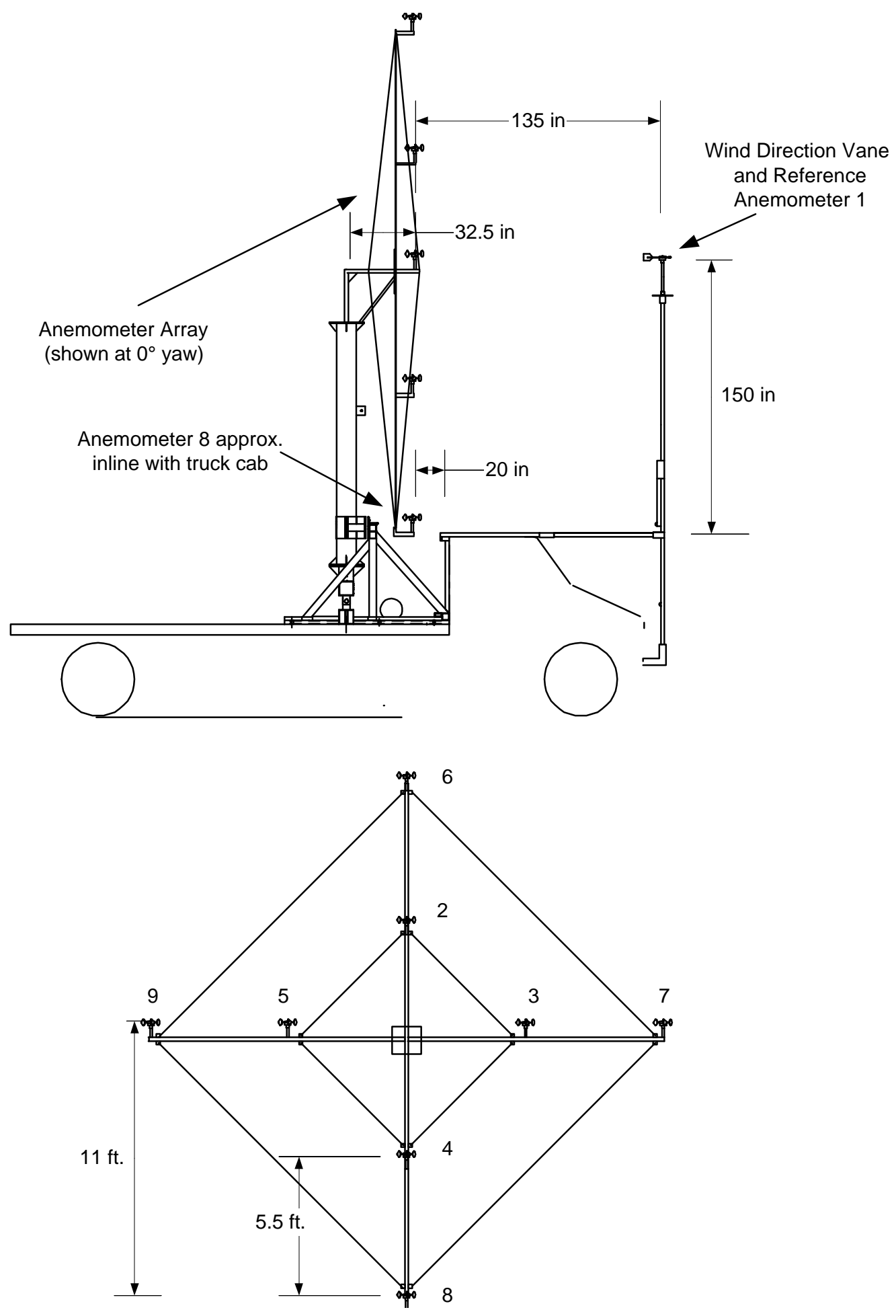

Figure 1. Anemometer array 
View from cab looking forward

18.75 inch spacing (2.5 diameters)

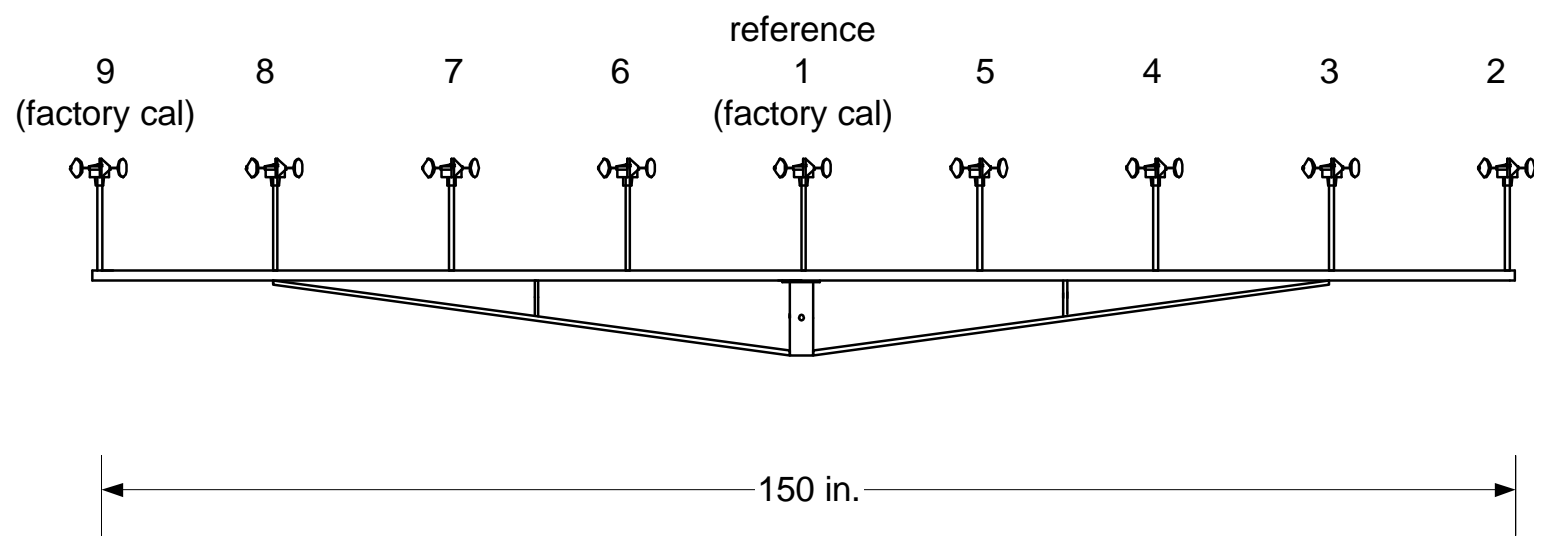

Figure 2. Anemometer Calibration Rig

NRG 40 Anemometers

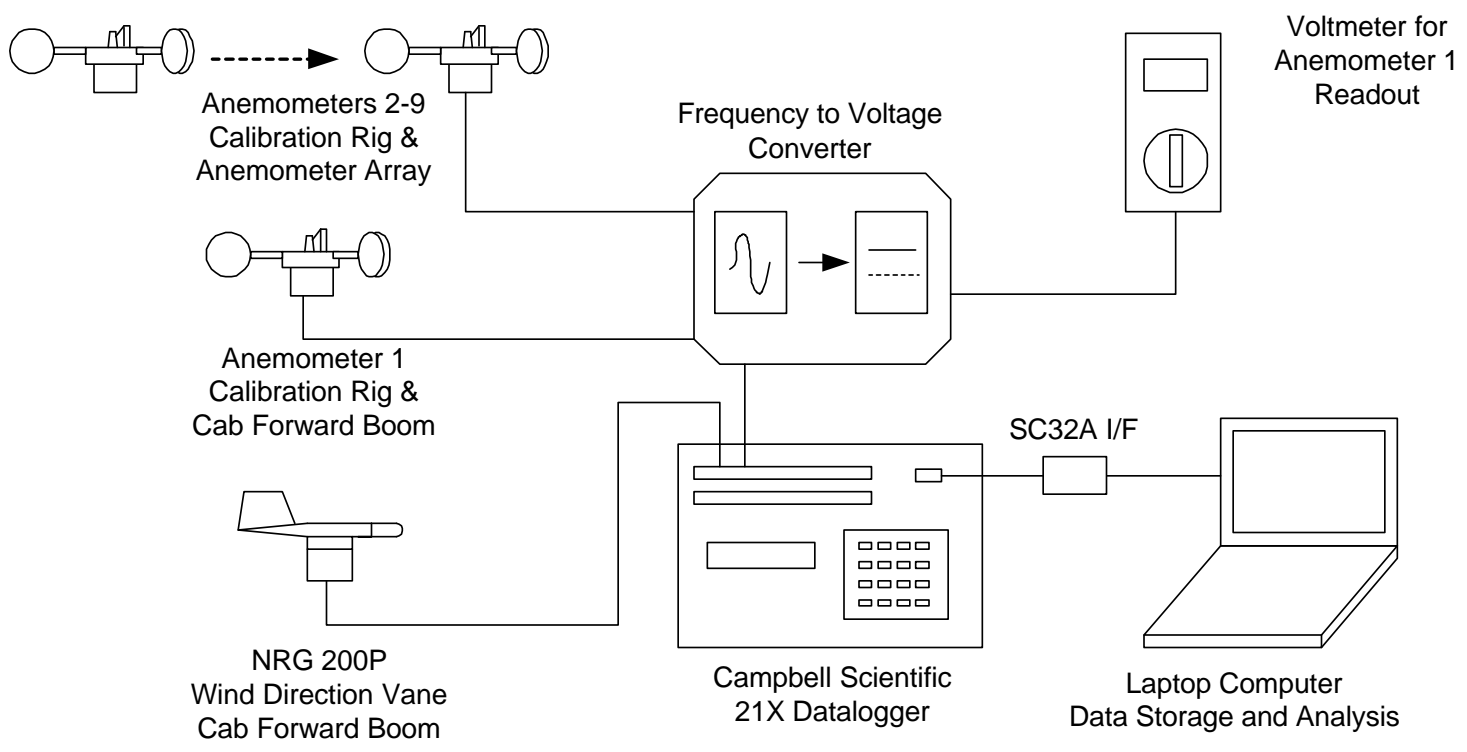

Figure 3. Data acquisition schematic 


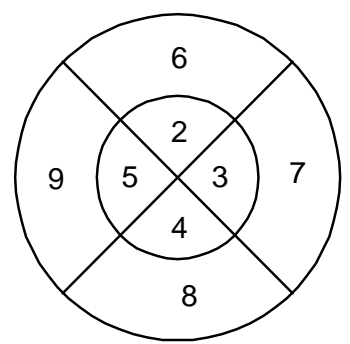

Legend

View from Upwind
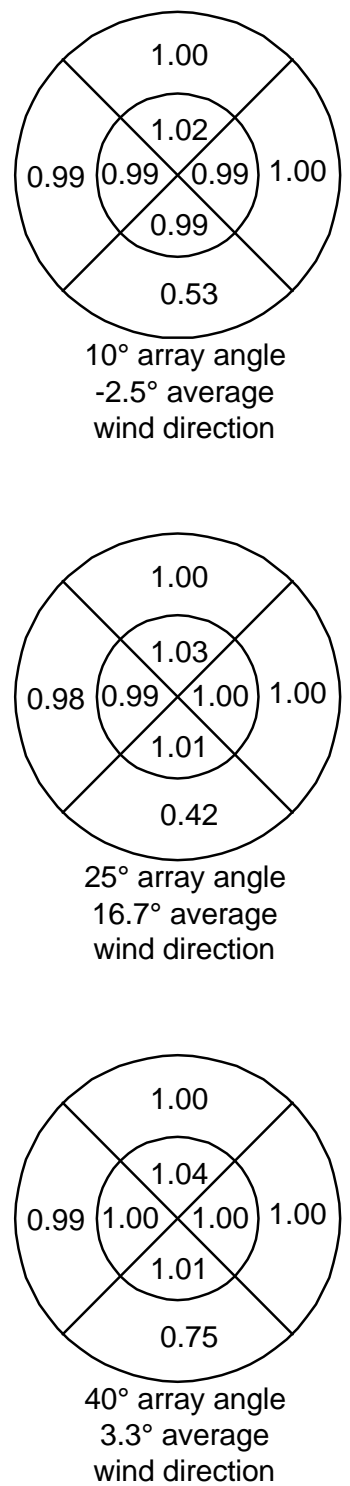
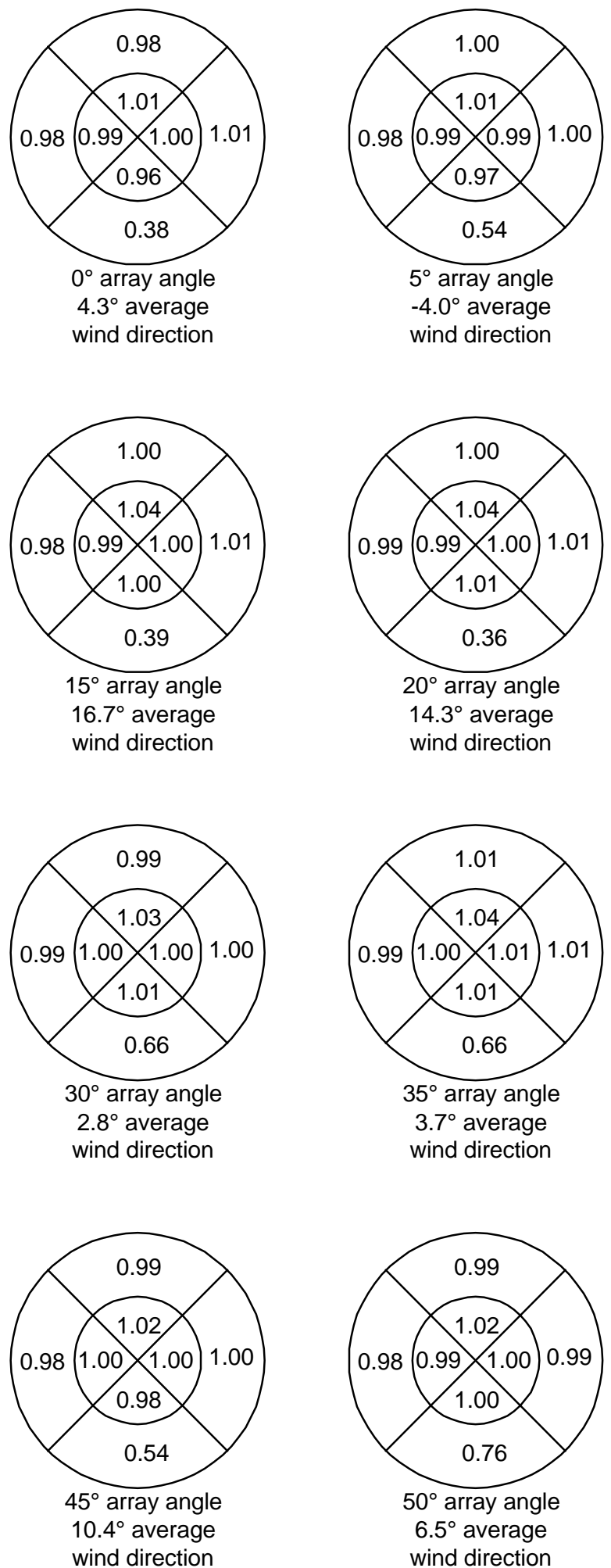

Figure 4. Average array anemometer readings normalized to anemometer 1. 

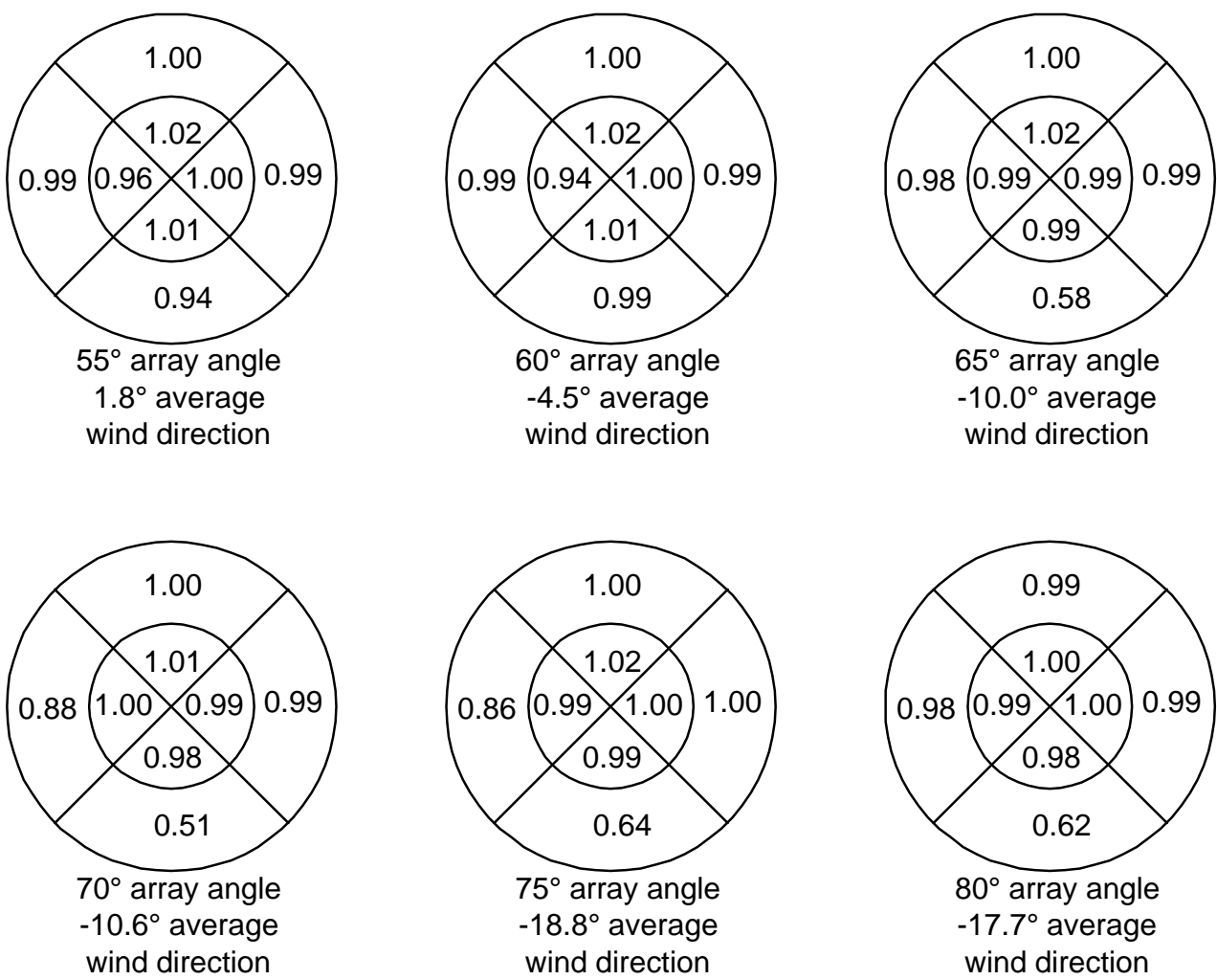

Figure 4-cont. Average array anemometer readings normalized to anemometer 1. 
TP-500-25714
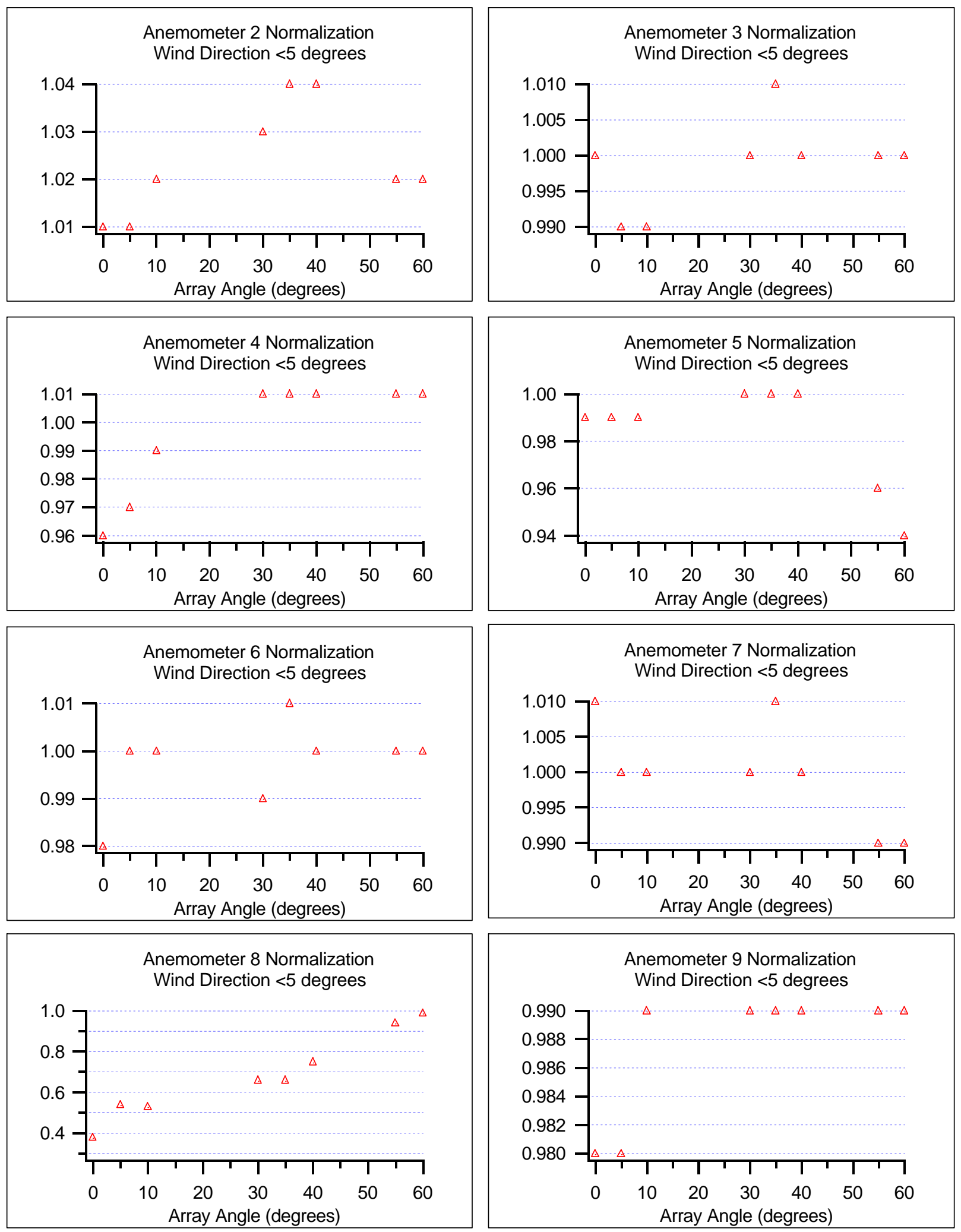

Figure 5. Normalized anemometer readings with average wind direction less than $5^{\circ}$. 


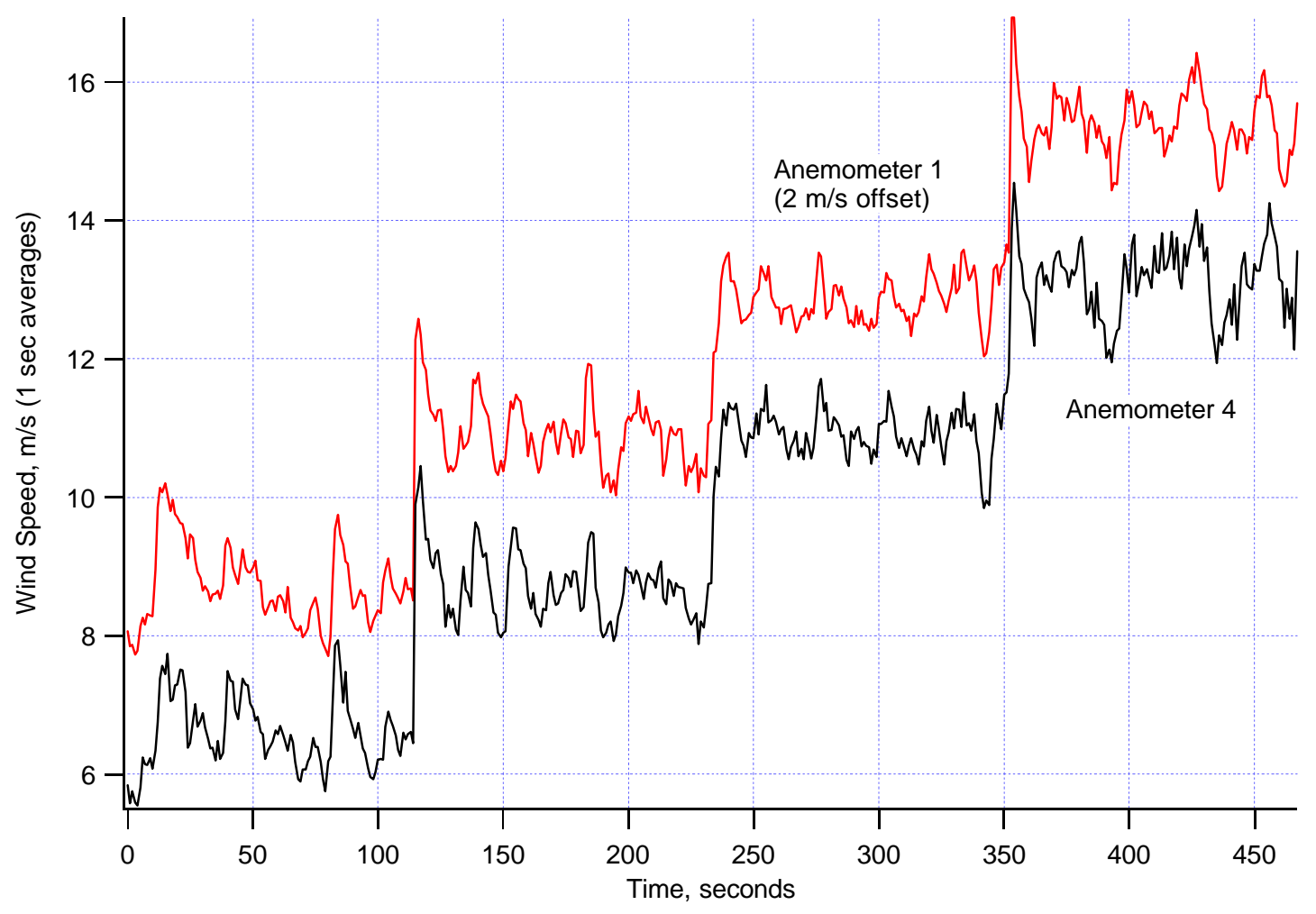

Figure 6. Anemometers 1 and 4 time-series at $10^{\circ}$ array angle.

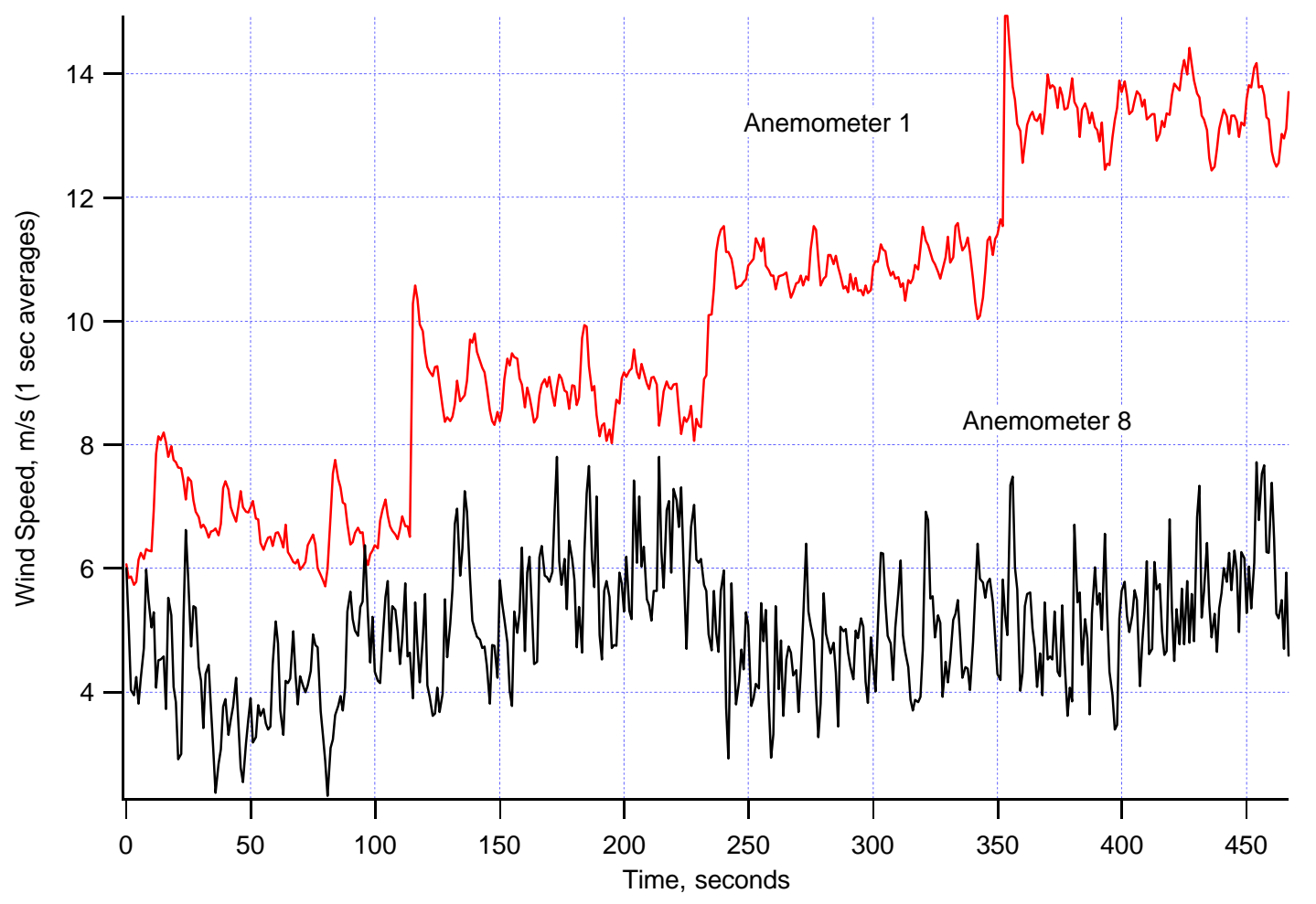

Figure 7. Anemometers 1 and 8 time-series at $10^{\circ}$ array angle. 


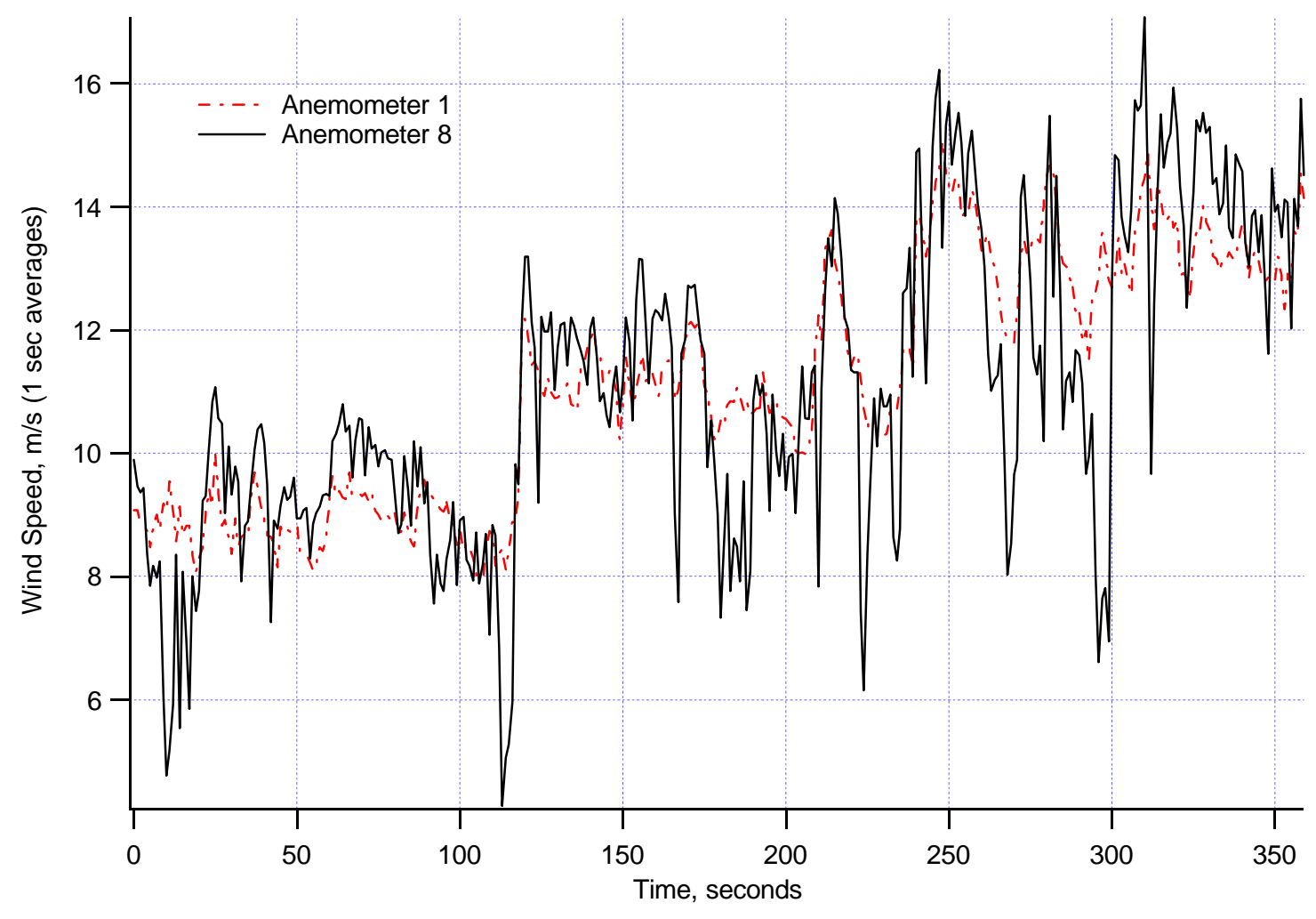

Figure 8. Anemometers 1 and 8 time-series at $60^{\circ}$ array angle. 
Public reporting burden for this collection of information is estimated to average 1 hour per response, including the time for review ing instructions, searching existing data sources, gathering and maintaining the data needed, and completing and review ing the collection of information. Send comments regarding this burden estimate or any other aspect of this collection of information, including suggestions for reducing this burden, to Washington Headquarters Services, Directorate for Information Operations and Reports, 1215 J efferson Davis Highway, Suite 1204, Arlington, VA 22202-4302, and to the Office of Management and Budget, Paperw ork Reduction Project (0704-0188), Washington, DC 20503.

\begin{tabular}{|l|l|l|l|l}
\hline 1. & $\begin{array}{l}\text { 2. REPORT DATE } \\
\text { November } 1998\end{array}$ & $\begin{array}{l}\text { 3. REPORT TYPE AND DATES COVERED } \\
\text { Technical Report }\end{array}$ \\
\hline
\end{tabular}

4. TITLE AND SUBTITLE

Measurement of Truck Cab Flow in Support of Wind Turbine Testing

6. AUTHOR(S)

Scott M. Larw ood, Brian Acker, J im Sencenbaugh

7. PERFORMING ORGANIZATION NAME(S) AND ADDRESS(ES)

National Renew able Energy Laboratory

1617 Cole Blvd.

Golden, CO 80401-3393
5. FUNDING NUMBERS

C:

TA: WE902330

8. PERFORMING ORGANIZATION REPORT NUMBER
9. SPONSORING/MONITORING AGENCY NAME(S) AND ADDRESS(ES)

National Renew able Energy Laboratory

1617 Cole Blvd.

Golden, CO 80401-3393
10. SPONSORING/MONITORING AGENCY REPORT NUMBER

TP-500-25714

11. SUPPLEMENTARY NOTES

12a. DISTRIBUTION/AVAILABILITY STATEMENT National Technical Information Service

U.S. Department of Commerce

5285 Port Royal Road

Springfield, VA 22161 12b. DISTRIBUTION CODE

13. ABSTRACT (Maximum 200 words)

This report describes an experiment to measure the airflow over a truck cab that can be used to conduct steady-state tests on an 8-kW wind turbine. The cab airflow measurements were made to document the turbine inflow for analytical models. The airflow measurements were made with an array of anemometers positioned to represent the turbine rotor disk. The data show ed that the influence of the truck cab was primarily in the lower sector of the rotor disk. The influence was negligible in the rest of the rotor disk.

\begin{tabular}{|c|c|c|c|c|c|c|c|}
\hline \multirow[t]{2}{*}{14.} & \multirow{2}{*}{\multicolumn{5}{|c|}{$\begin{array}{l}\text { SUBJ ECT TERMS } \\
\text { renew able energy; wind energy; wind turbines; wind turbine testing; truck testing; truck } \\
\text { cab flow }\end{array}$}} & 15. & NUMBER OF PAGES \\
\hline & & & & & & 16. & PRICE CODE \\
\hline 17. & $\begin{array}{l}\text { SECURITY } \\
\text { CLASSIFICATION } \\
\text { OF REPORT } \\
\text { Unclassified }\end{array}$ & 18. & $\begin{array}{l}\text { SECURITY } \\
\text { CLASSIFICATION } \\
\text { OF THIS PAGE } \\
\text { Unclassified }\end{array}$ & & $\begin{array}{l}\text { SECURITY } \\
\text { CLASSIFICATION } \\
\text { OF ABSTRACT } \\
\text { Unclassified }\end{array}$ & 20. & $\begin{array}{l}\text { LIMITATION OF ABSTRACT } \\
\text { UL }\end{array}$ \\
\hline
\end{tabular}

NSN 7540-01-280-5500

Standard Form 298 (Rev. 2-89) Prescribed by ANSI Std. Z39-18 